\title{
Awareness of Prevention Strategies and Willingness to Use Preexposure Prophylaxis in Brazilian Men Who Have Sex With Men Using Apps for Sexual Encounters: Online Cross-Sectional Study
}

Thiago Silva Torres ${ }^{1}$, MSc, PhD; Raquel Brandini De Boni ${ }^{1}$, MD, PhD; Mauricio TL de Vasconcellos ${ }^{2}$, PhD; Paula Mendes Luz ${ }^{1}, \mathrm{MD}, \mathrm{PhD}$; Brenda Hoagland ${ }^{1}, \mathrm{MD}, \mathrm{PhD}$; Ronaldo Ismerio Moreira ${ }^{1}, \mathrm{MSc}_{\text {; Valdilea Gonçalves Veloso }}{ }^{1}$, $\mathrm{MD}, \mathrm{PhD}$; Beatriz Grinsztejn ${ }^{1}$, MD, PhD

\footnotetext{
${ }_{1}^{1}$ Instituto Nacional de Infectologia Evandro Chagas, Fundação Oswaldo Cruz, Rio de Janeiro, Brazil

${ }^{2}$ Escola Nacional de Ciências Estatísticas, Rio de Janeiro, Brazil
}

\section{Corresponding Author:}

Thiago Silva Torres, MSc, PhD

Instituto Nacional de Infectologia Evandro Chagas, Fundação Oswaldo Cruz

Av Brasil 4365 Manguinhos

Rio de Janeiro, 21040-360

Brazil

Phone: 5521995363616

Fax: 552138659573

Email: thiago.torres@ini.fiocruz.br

\section{Abstract}

Background: Geosocial networking (GSN) smartphone apps are becoming the main venue for sexual encounters among Brazilian men who have sex with men (MSM). To address the increased HIV incidence in this population, preexposure prophylaxis (PrEP) was recently implemented in the Brazilian public health system in the context of combined HIV prevention.

Objective: This study aimed to describe the characteristics of MSM using GSN apps for sexual encounters, their awareness of prevention strategies, and willingness to use PrEP.

Methods: This study was an online cross-sectional study conducted in 10 Brazilian state capitals from July 1 to July $31,2016$. The questionnaire was programmed on SurveyGizmo and advertised in two GSN apps used by MSM to find sexual partners (Hornet and Grindr). Inclusion criteria were $>18$ years of age, cisgender men, with an HIV-negative status. Eligible individuals answered questions on: demographics; behavior; and knowledge, preferences, and willingness to use PrEP, nonoccupational postexposure prophylaxis (nPEP), HIV self-testing (HIVST), and condoms. Logistic regression modeling was performed to assess the factors associated with daily oral PrEP willingness.

Results: During the study period, 8885 individuals provided consent and started the questionnaire. Of these, 23.05\% (2048/8885) were ineligible, $6837(6837 / 8885,76.94 \%)$ initiated, and $5065(5065 / 8885,57.00 \%)$ completed the entire questionnaire and were included in the present analysis. Median age was 30 years (interquartile range: 25-36), most self-declared as MSM (4991/5065, $98.54 \%)$, white $(3194 / 5065,63.06 \%)$, middle income $(2148 / 5065,42.41 \%)$, and had 12 or more years of schooling (3106/5062, $61.36 \%)$. The majority of MSM (3363/5064, 66.41\%) scored >10 points (high risk) on The HIV Incidence Risk for MSM Scale, but only $21.39 \%(1083 / 5064)$ had a low perceived likelihood of getting HIV in the next year. Daily use of apps for sex was reported by 35.58\% (1798/5054). Most MSM (4327/5065, 85.43\%) reported testing for HIV at least once in their lifetime and 9.16\% (464/5065) used nPEP in the previous year. PrEP, nPEP, and HIVST awareness was reported by 57.89\% (2932/5065), $57.39 \%(2907 / 5065)$, and $26.57 \%$ (1346/5065) of participants, respectively. Half of all respondents $(2653 / 5065,52.38 \%)$ were willing to use daily oral PrEP, and this finding was associated with higher numbers of male sexual partners (adjusted odds ratio [AOR] 1.26, 95\% CI 1.09-1.47), condomless receptive anal intercourse (AOR 1.27, 95\% CI 1.12-1.44), sex with HIV-positive partner versus no HIV-positive partner (one HIV-positive partner: AOR 1.36, 95\% CI 1.11-1.67), daily use of apps for sexual encounters (AOR 1.48, 95\% CI 1.17-1.87), high and unknown perceived likelihood of getting HIV in the next year (AOR 1.72, 95\% CI 1.47-2.02 and AOR 1.39, 95\% CI 1.13-1.70), sexually transmitted infection diagnosis (AOR 1.25, 95\% CI 1.03-1.51), 
stimulant use (AOR 1.24, 95\% CI 1.07-1.43), PrEP awareness (AOR 1.48, 95\% CI 1.30-1.70), and unwillingness to use condoms (AOR 1.16, 95\% CI 1.00-1.33).

Conclusions: Our results evidenced high-risk scores in the studied population, suggesting the importance of PrEP use. Those individuals presenting risky sexual behaviors were more willing to use PrEP. Nonetheless, only 58\% (2932/5065) of individuals had heard about this prevention strategy. Efforts to increase awareness of new prevention strategies are needed, and mobile health tools are a promising strategy to reach MSM.

(JMIR Public Health Surveill 2018;4(1):e11) doi: 10.2196/publichealth.8997

\section{KEYWORDS}

HIV; prevention; MSM; app; internet; PrEP; Brazil; Latin America

\section{Introduction}

Brazil has the largest population of individuals living with HIV and acquired immune deficiency syndrome (AIDS) in Latin America [1], representing a concentrated epidemic with an estimated HIV prevalence of $0.6 \%$ in the general population ( $0.4 \%$ among women and $0.8 \%$ among men), and a $14.2 \%$ prevalence among men who have sex with men (MSM) [2]. Geographic differences have been reported in HIV prevalence among MSM (ranging from 5.2\% [Recife] to $23.7 \%$ [Brasília]) in a respondent-driven sample survey conducted in 10 cities [2]. In 2016, approximately $60 \%$ of reported HIV infections were attributed to male-to-male sexual contact, although MSM represent only $3.5 \%$ of the Brazilian population [3,4]. New infections in this population continue to rise, especially among young people (24 years-old or less) [3].

Preexposure prophylaxis (PrEP) with tenofovir/emtricitabine is now a key component of prevention packages for MSM. The efficacy of treatment for this population has been shown with both once daily and on-demand use in clinical trials and open-label studies [5-9], and demonstration studies have been successfully implemented in different settings [10-13]. Results show that willingness to use PrEP among MSM may vary across different geographic locations, ranging from $32 \%$ to $92 \%$ [14-28].

With expanded access to the Internet via mobile phones, geosocial networking (GSN) smartphone apps are becoming the main venue for casual sexual encounters [29-32]. MSM report logging into GSN apps at least three times per day, with an average of 12 minutes spent per log-in [33,34]. These new technologies have generated quicker and easier ways for MSM to meet potential partners, and may facilitate the users' ability to have multiple concurrent partners, thereby increasing their risk for acquiring HIV [32,35-37]. Men who use the Internet to meet other men may present a different behavioral profile than men who meet men in physical venues. For instance, MSM who do not identify as such would be excluded from venue-sampling [38]. Therefore, a better understanding of the profile of MSM who use apps for sexual encounters is needed in order to design tailored, combined prevention interventions. This study aimed to describe the characteristics of Brazilian MSM using two GSN apps for sexual encounters, including risk behavior for HIV infection and their awareness of prevention strategies. In addition, factors associated with daily oral PrEP willingness were assessed.

\section{Methods}

\section{Study Design}

This was a cross-sectional online study targeting MSM from 10 Brazilian capitals (two from each Brazilian geographical region): Belém and Manaus (North); Salvador and Recife (Northeast); Brasília and Goiânia (Central-West); Florianópolis and Porto Alegre (South); and Rio de Janeiro and São Paulo (Southeast). According to the 2010 Brazilian Population Census, these are the cities with the greatest number of MSM couples from each region [39]. Individuals who met eligibility criteria (age >18 years, cisgender men, and HIV-uninfected) and who acknowledged reading the informed consent were directed to the online questionnaire.

The questionnaire was programmed on SurveyGizmo [40] and the project was advertised on two GSN apps: Hornet [41] and Grindr [42]. Hornet users received an inbox message with a link to the survey on July 1, 2016 and July 22, 2016. Grindr users received a pop-up advertisement in July 2016 (days 9, 13, 17, 23,27 ). In addition, a total of 5,050,000 banners were advertised on the Grindr interface. The questionnaire remained open from July 1, 2016 to July 31, 2016. No incentives were provided for answering the survey.

\section{Variables}

\section{Sociodemographics}

Age was categorized into three brackets: (1) 18-to-24 years; (2) 25-to-34 years; and (3) >35 years. Skin color/race was dichotomized into "white" or "non-white" (Black, Asian, Native American, mixed-race, or don't know). Schooling was dichotomized into " $<12$ years" and ">12 years" (12 years is equivalent to completing high school education in Brazil). Family monthly income was grouped into " $<3$ " (low income), "4-to-10" (middle income), and "> 10" minimum (high income) wages (Brazilian minimum wage was 880 BRL or US \$267 dollars in July 2016). Sexual orientation was dichotomized into "MSM" (homosexual/gay/bisexual) or "other", and the options for a question regarding their friends with the same sexual orientation were "none", "a few", and "majority". Individuals were asked if they had a steady partner and the options were "yes/no", "male" and "female".

\section{Substance Use}

Binge drinking [43] was evaluated with the question, "In the last 6 months, did you drink 5 or more drinks in a couple of 
hours?" Any substance use in the prior six months considered the use of any of the following: tobacco (cigarettes), stimulants (cocaine, crack, amphetamines), 4-hydroxybutanoic acid (GHB), marijuana or hash, and hallucinogens (solvents, lysergic acid diethylamide, ketamine), which were displayed in a predefined list of all substances.

\section{Use of Apps}

The variable "Apps" was created based on the question, "Where did you hear about this questionnaire?" (with response format as open text) and was categorized into Hornet, Grindr, and other. Although the project was advertised only on Hornet and Grindr, the link to the survey could be copied and exchanged through other media (ie, email, Facebook, Whatsapp). The use of apps for sexual encounters was categorized into "never", "sometimes" (once a month, once a week, only on weekends), "daily", and "only when traveling or vacations".

\section{Sexual Behavior, Sexually Transmitted Diseases, and Nonoccupational Postexposure Prophylaxis}

Sexual behavior in the last six months was assessed through the following questions: number of partners $(0-5,>6-10$, and more than 10); condomless receptive anal sex (yes or no); sex with HIV-positive partner (no, one, more than one, or unknown); number of insertive anal intercourses with HIV-positive partner (no, 1-4 intercourses, 5 or more intercourses, or unknown). These questions belong to The HIV Incidence Risk for MSM Scale, which is a 7-item questionnaire developed by Smith et al [44] to predict HIV seroconversion among MSM. It is recommended by the Centers for Disease Control and Prevention (CDC) to screen individuals who should be evaluated to receive PrEP [45]. Scores $>10$ were considered "high risk" $[44,45]$. Sex for money and sexually transmitted infections (STIs; syphilis, gonorrhea or rectal chlamydia) were dichotomized into "yes" or "no". Participants were asked if they used nonoccupational postexposure prophylaxis (nPEP) in the past 12 months.

\section{Perceived Likelihood of Getting HIV in Next Year and HIV Testing}

Perceived likelihood of getting HIV in the next year was assessed through the question, "What is your chance of getting HIV in the next year?" with possible options grouped into "Low" (None/Low), "High" (Some/High/Certainly) and "unknown" [21]. Additionally, individuals were asked about previous HIV testing (never, once in lifetime, once a year, more than once a year, every time I am exposed, or sporadically) and preferences (reasons for not testing, best place for testing, best way to obtain HIV self-testing (HIVST) if available at the Brazilian public health system; SUS), as well as if they know someone living with HIV (Yes/No).

\section{Awareness and Willingness to Use HIV Prevention Measures}

Awareness of HIV prevention measures including daily PrEP, postexposure prophylaxis (PEP), and HIVST were assessed through the question, "Have you ever heard of...to prevent HIV infection?" Willingness to use HIV prevention measures including condoms, daily oral PrEP, and PEP was defined as the "High interest" option on a four-point Likert scale through the question, "In case it was available at SUS, what level of interest would you have in using...for preventing HIV?" A brief explanation on the preventive measures was provided before these questions were asked. These questions have previously been used by our research team to describe PrEP awareness and willingness [21]. Finally, we assessed individuals' willingness to use PrEP and HIV self-testing even if they had to pay for it.

Willingness to use different PrEP regimens was assessed with the following question, "Which of the following PrEP regimens would you take if available?" Participants could select one or more of the following options: "PrEP on demand" (two pills 24 hours before intercourse and one pill 24 hours and 48 hours after), "injection PrEP" (injection drug every 2 months), or "would never use PrEP".

\section{Ethical Issues}

Instituto Nacional de Infectologia Evandro Chagas INI-FIOCRUZ institutional review board approved this study (\#51595815.7.0000.5262 at "Plataforma Brasil") in accordance with all applicable regulations, and all study participants digitally signed an informed consent form. No identification of participants was collected.

\section{Statistical Analysis}

Characteristics, attitudes, and behaviors of the participants were described by their absolute and relative frequencies. Chi-square tests were used to compare characteristics of the individuals who completed and did not complete the questionnaire. A bivariate logistic regression analysis was performed to explore factors associated with willingness to use oral daily PrEP (odds ratios $[\mathrm{OR}]$ ). Afterwards, a backwards stepwise logistic regression modeling approach was used to identify the factors independently associated with daily oral PrEP willingness [46]. Variables with $P<.25$ in bivariate analysis models were included in the initial multivariate model, and subsequently excluded if their P-value was >.05. The final multivariate model included both variables that remained significant (at a 5\% significance threshold) and those found to be confounders (ie, those that changed the OR estimate of any of the remaining variables by more than 10\%). Age, color/race, and schooling were defined a priori as confounders and were kept in the final multivariate model irrespectively of significance level (adjusted odds ratios [AOR]). Analyses were performed using PROC GENMOD available in the Software SAS [47].

\section{Results}

During the 30 days of the online survey, 8885 individuals provided informed consent. Of these, $23.05 \%$ (2048/8885) were ineligible, $6837(6837 / 8885,76.94 \%)$ initiated the questionnaire, and $5065(5065 / 8885,57.00 \%)$ completed the questionnaire and were included in the present analysis (Figure 1). Differences among those who did not complete the questionnaire $(n=1772)$ and those who completed the questionnaire $(n=5065)$ are presented in Table 1. 
Figure 1. Study flow-chart.

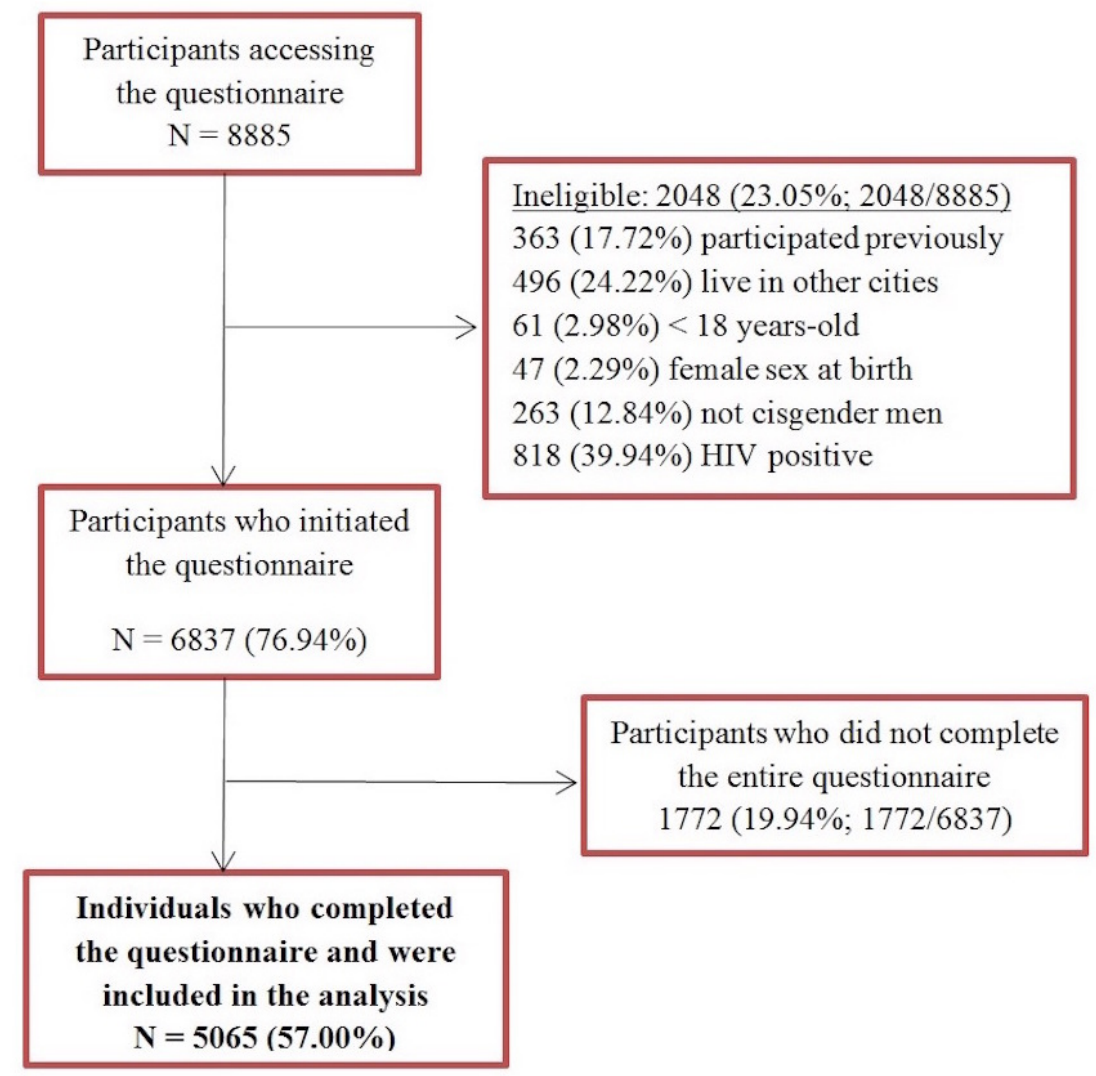

Among all individuals who accessed the questionnaire and completed questions regarding HIV serostatus ( $n=6664)$, HIV prevalence was $12.27 \%$ (818/6664). Considering ineligible respondents $(\mathrm{n}=2048), 2.29 \% \quad(47 / 2048)$ self-declared as cisgender women, $1.56 \%(32 / 2048)$ as transgender women or transvestites, $1.95 \%$ (40/2048) as transgender men, and $9.33 \%$ $(191 / 2048)$ as other genders.

Among those included in this analysis $(n=5065)$, most participants were from southeast Brazil (3532/5065, 69.73\%) and accessed the survey through the Hornet app (2800/5065, $55.28 \%)$, and a total of $4618(4618 / 5054,91.37 \%)$ respondents used apps for sexual encounters. The median age of the cohort was 30 years old (interquartile range: 25-36), 63.06\% (3194/5065) were white, $68.13 \% \quad(3541 / 5065)$ reported middle-to-high income, and 61.36\% (3106/5062) reported more than 12 years of schooling. Most respondents identified themselves as MSM (4991/5065, 98.54\%) and reported having friends with the same sexual orientation $(3368 / 5065,66.50 \%)$. Only $20.48 \%$ (1029/5024) of respondents reported a male steady partner and 3.97\% (198/4986) reported a female steady partner (Table 1).

Binge drinking and tobacco use in the last six months were reported by $71.79 \%(3636 / 5050)$ and $32.60 \%(1651 / 5065)$ of individuals, respectively (Table 2). Marijuana (or hash) was the most frequent illicit substance reported (1679/5065, 33.15\%), followed by stimulants $(1177 / 5065,23.24 \%)$, hallucinogens
$(519 / 5065,10.25 \%)$ and GHB $(222 / 5065,4.38 \%)$. A total of $2305(2305 / 5065,45.51 \%)$ participants reported no substance use in the last six months.

In the previous 6 months, only 236 (236/5065, 4.66\%) respondents reported having no sexual partners. Condomless receptive anal sex prevalence was high $(2121 / 5065,41.88 \%)$. Approximately $10 \%(480 / 5065,9.48 \%)$ of respondents reported having had sex with one HIV-positive partner, 2.19\% (111/5064) with more than one partner, and 18.62\% (943/5064) reported that they did not know how many HIV-positive partners they had sex in the prior six months. Regarding the number of times they were the insertive partner without a condom with an HIV-positive partner, $18.90 \%(957 / 5064)$ of participants reported one to four times and $8.87 \%$ (449/5064) reported five times or more. Reported prevalence of STIs (syphilis, gonorrhea, or rectal chlamydia) in the previous 6 months was $12.06 \%$ (604/5010; Table 2). Most of the participants (3363/5064, $66.41 \%$ ) scored $>10$ points in The HIV Incidence Risk for MSM Scale (high HIV risk) and fall into the category of individuals who should undergo evaluation for PrEP use. Conversely, only $21.39 \%(1083 / 5064)$ of participants had high HIV risk perception and $9.16 \%(464 / 5065)$ reported nPEP use in the last 12 months. Among those that used PEP, 81.68\% (379/464), $12.72 \%$ (59/464), $2.59 \%$ (12/464), and 3.02\% (14/464) reported nPEP use once, twice, three times, and more than three times in the past 12 months (respectively). 
Table 1. Characteristics of the individuals who completed and did not complete the questionnaire.

\begin{tabular}{|c|c|c|c|c|}
\hline Parameter & Incomplete $^{\mathrm{a}}, \mathrm{n}(\%)$ & Complete, n (\%) & Total, n (\%) & $P$ value $^{\mathrm{b}}$ \\
\hline Region & & & & .01 \\
\hline North (Manaus and Belém) & $72(6.30)$ & $185(3.65)$ & $257(4.14)$ & \\
\hline Northeast (Salvador and Recife) & $112(9.81)$ & $442(8.73)$ & $354(8.93)$ & \\
\hline Central-West (Brasília and Goiânia) & $102(8.93)$ & $500(9.87)$ & $602(9.70)$ & \\
\hline South (Florianópolis and Porto Alegre) & $90(7.88)$ & $406(8.01)$ & $496(7.99)$ & \\
\hline Rio de Janeiro $^{c}$ & $281(24.61)$ & $1225(24.19)$ & $1506(24.26)$ & \\
\hline São Paulo ${ }^{c}$ & $485(42.57)$ & $2307(45.55)$ & $2792(44.98)$ & \\
\hline Total & $1142(18.40)$ & $5065(81.60)$ & $6207(100.00)$ & \\
\hline Apps & & & & $<.001$ \\
\hline Hornet & $493(42.28)$ & $2800(55.28)$ & $3293(58.85)$ & \\
\hline Grindr & $430(36.88)$ & $1867(36.86)$ & $2297(36.86)$ & \\
\hline Other $^{\mathrm{d}}$ & $243(20.84)$ & $398(7.86)$ & $641(10.29)$ & \\
\hline Total & $1166(18.71)$ & $5065(81.29)$ & $6231(100.00)$ & \\
\hline Age (years) & & & & .12 \\
\hline $18-24$ & $262(26.60)$ & $1212(23.93)$ & $1474(24.36)$ & \\
\hline $25-35$ & $458(46.50)$ & $2515(49.65)$ & $2973(49.14)$ & \\
\hline$>36$ & $265(26.90)$ & $1338(26.42)$ & $1603(26.50)$ & \\
\hline Total & $985(16.28)$ & $5065(83.72)$ & $6050(100.00)$ & \\
\hline Color/Race & & & & - \\
\hline White & - & $3194(63.06)$ & $3194(63.06)$ & \\
\hline Non-white ${ }^{\mathrm{e}}$ & - & $1871(36.94)$ & $1871(36.94)$ & \\
\hline Total & - & $5065(100.00)$ & $5065(100.00)$ & \\
\hline Family monthly income ${ }^{f}$ & & & & - \\
\hline$<3$ (low income) & - & $1614(31.87)$ & $1614(31.87)$ & \\
\hline 4-10 (middle income) & - & $2148(42.41)$ & $2148(42.41)$ & \\
\hline$>10$ (high income) & - & $1303(25.73)$ & $1303(25.73)$ & \\
\hline Total & - & $5065(100.00)$ & $5065(100.00)$ & \\
\hline Schooling (years) & & & & .01 \\
\hline$<12$ & $391(45.41)$ & $1956(38.64)$ & $2347(39.63)$ & \\
\hline$>12$ & $470(54.59)$ & $3106(61.36)$ & $3576(60.37)$ & \\
\hline Total & $861(14.54)$ & $5062(85.46)$ & $5923(100.00)$ & \\
\hline Sexual orientation & & & & $<.001$ \\
\hline $\operatorname{MSM}^{\mathrm{g}}$ & $839(96.11)$ & 4991 (98.54) & $5042(84.97)$ & \\
\hline Other & $34(3.89)$ & $74(1.46)$ & $892(15.03)$ & \\
\hline Total & $869(14.64)$ & $5065(85.30)$ & $5934(100.00)$ & \\
\hline Friends with same sexual orientation & & & & .01 \\
\hline Majority & $433(56.72)$ & $3368(66.50)$ & $3801(65.65)$ & \\
\hline A few & $292(40.28)$ & $1697(33.51)$ & $1989(34.35)$ & \\
\hline Total & $725(12.52)$ & $5065(87.48)$ & $5790(100.00)$ & \\
\hline
\end{tabular}




\begin{tabular}{|c|c|c|c|c|}
\hline Parameter & Incomplete $^{\mathrm{a}}, \mathrm{n}(\%)$ & Complete, n (\%) & Total, n (\%) & $P$ value $^{\mathrm{b}}$ \\
\hline Steady partner (male) & & & & .02 \\
\hline Yes & $205(24.09)$ & $1029(20.48)$ & $1234(21.00)$ & \\
\hline No & $646(75.91)$ & $3995(79.52)$ & $4641(79.00)$ & \\
\hline Total & $851(14.49)$ & $5024(85.51)$ & $5875(100.00)$ & \\
\hline Steady partner (female) & & & & .08 \\
\hline Yes & $44(5.28)$ & $198(3.97)$ & $242(4.16)$ & \\
\hline No & $789(94.72)$ & $4788(96.02)$ & $5577(95.84)$ & \\
\hline Total & $833(14.32)$ & $4986(85.68)$ & $5819(100.00)$ & \\
\hline Know someone living with HIV & & & & .01 \\
\hline Yes & $263(31.0)$ & $3491(68.94)$ & $1856(31.72)$ & \\
\hline No & $462(68.94)$ & $1573(31.06)$ & $3953(68.28)$ & \\
\hline Total & $725(12.54)$ & $5064(87.48)$ & $5789(100.00)$ & \\
\hline Use of apps for sexual encounters & & & & .02 \\
\hline Never & $85(11.74)$ & $436(8.63)$ & $521(9.02)$ & \\
\hline Sometimes & $338(46.69)$ & $2564(50.72)$ & $2902(50.22)$ & \\
\hline Daily & $259(35.77)$ & $1798(35.58)$ & $2057(35.60)$ & \\
\hline Only when travelling or vacations & $42(5.80)$ & $256(5.07)$ & $298(5.16)$ & \\
\hline Total & $724(12.53)$ & $5054(87.47)$ & $5778(100.00)$ & \\
\hline
\end{tabular}

${ }^{\mathrm{a}}$ No answer for variables color and race (last questions of the questionnaire).

${ }^{\mathrm{b}}$ Chi-square test.

${ }^{\mathrm{c}}$ Southeast Brazil.

${ }^{\mathrm{d}}$ Other social media (eg, Facebook, WhatsApp), email.

${ }^{\mathrm{e}}$ Black, Asian, Native American, mixed-race, or don't know.

f Brazilian monthly minimum wage in 2016 was 880 BRL (US \$267, currency from July 2016).

$\mathrm{g}_{\text {Homosexual, gay, or bisexual. }}$

A total of $738(738 / 5065,14.57 \%)$ respondents had never performed an HIV test and one of the main reasons was the fear of having an HIV-positive result $(263 / 738,35.64 \%)$. Compared to those who had been tested before, these respondents were younger (24 years old, interquartile range: $21-30)$, had less years of schooling ( $<12$ years: 495/736, 67.26\%), had lower income (less than 4 minimum wage: $359 / 738,48.64 \%$ ), and almost half self-reported as white $(370 / 738,50.14 \%)$. Almost half of the respondents believed that the best testing venue is at home $(2400 / 5065,47.38 \%)$ and most would be comfortable with picking up the HIVST somewhere else (2867/5065, 56.60\%; Table 3).

PrEP, nPEP and HIVST awareness was reported by $57.89 \%$ (2932/5065), 57.39\% (2907/5065), and 26.57\% (1346/5065) of respondents, respectively. Willingness to use different HIV prevention methods is depicted in Figure 2. Willingness to use daily oral PrEP and injected PrEP was similar (2653/5065, $52.38 \%$ vs $2408 / 5065,47.48 \%$ ), while PrEP on demand was lower $(1751 / 5065,35.57 \%)$ and PrEP during short periods or vacations was much higher $(4652 / 5065,91.85 \%)$. In addition, $51.08 \%(2587 / 5065)$ of respondents would use PrEP if available commercially and $4.72 \%$ (239/5065) would never use PrEP.

In the final multivariate model (Multimedia Appendix 1), variables independently associated with daily oral PrEP willingness were: high number of male sexual partners $(>10)$ versus $0-5$ partners (AOR 1.26, 95\% CI 1.09-1.47), condomless receptive anal intercourse (AOR 1.27, 95\% CI 1.12-1.44), sex with HIV-positive partner versus no HIV-positive partner (one HIV-positive partner: AOR 1.36, 95\% CI 1.11-1.67), daily use of apps for sexual encounters versus never use (AOR 1.48, 95\% CI 1.17-1.87), high and unknown perceived likelihood of getting HIV in the next year (AOR 1.72, 95\% CI 1.47-2.02 and AOR $1.39,95 \%$ CI 1.13-1.70), STI diagnosis (AOR 1.25, 95\% CI 1.03-1.51), stimulant use (AOR 1.24, 95\% CI 1.07-1.43), PrEP awareness (AOR 1.48, 95\% CI 1.30-1.70), and unwillingness to use condoms (AOR 1.16, 95\% CI 1.00-1.33). 
Table 2. Binge drinking, substance use, and risk behaviors among the study population ( $\mathrm{n}=5065)$. MSM: men who have sex with men.

\begin{tabular}{|c|c|}
\hline Parameter & Total, n (\%) \\
\hline Binge drinking ${ }^{\mathrm{a}}(\mathrm{yes} ; \mathrm{n}=5050)$ & $3636(71.79)$ \\
\hline \multicolumn{2}{|l|}{ Substance use $^{\text {a }}$} \\
\hline Tobacco & $1651(32.60)$ \\
\hline Stimulants ${ }^{\mathrm{b}}$ & $1177(23.24)$ \\
\hline $\mathrm{GHB}^{\mathrm{c}}$ & $222(4.38)$ \\
\hline Marijuana or hash & $1679(33.15)$ \\
\hline Hallucinogens $^{\mathrm{d}}$ & $519(10.25)$ \\
\hline \multicolumn{2}{|l|}{ Number of male sexual partners ${ }^{a}$} \\
\hline $0-5$ & $2609(51.51)$ \\
\hline $6-10$ & $1001(19.76)$ \\
\hline$>10$ & $1455(28.73)$ \\
\hline Condomless receptive anal $\operatorname{sex}^{\mathrm{a}}$ (yes) & $2121(41.88)$ \\
\hline \multicolumn{2}{|l|}{ Number of male HIV-positive sexual partner(s) ${ }^{a}(n=5064)$} \\
\hline None & $3530(69.71)$ \\
\hline 1 & $480(9.48)$ \\
\hline$>1$ & $111(2.19)$ \\
\hline Unknown & $943(18.62)$ \\
\hline \multicolumn{2}{|c|}{ Number of insertive condomless anal intercourse with HIV-positive partner ${ }^{a}(\mathbf{n}=5064)$} \\
\hline None & $3391(66.96)$ \\
\hline $1-4$ intercourses & $957(18.90)$ \\
\hline 5 or more intercourses & $449(8.87)$ \\
\hline Unknown & $267(5.27)$ \\
\hline The HIV Incidence Risk for MSM Scale ${ }^{\mathrm{e}, \mathrm{f}}$ (>10 points; high risk) & $3363(66.41)$ \\
\hline Money for $\operatorname{sex}^{\mathrm{a}}(\mathrm{n}=5045)$ & $202(3.99)$ \\
\hline \multicolumn{2}{|l|}{ Perceived likelihood of getting HIV ${ }^{g}$} \\
\hline Low & $3516(69.41)$ \\
\hline High & $1083(21.39)$ \\
\hline Unknown & $466(9.20)$ \\
\hline STI diagnosis ${ }^{\mathrm{a}, \mathrm{h}}(\mathrm{n}=5010)$ & $604(12.06)$ \\
\hline
\end{tabular}

${ }^{\mathrm{a}}$ During the previous 6 months.

${ }^{\mathrm{b}}$ Cocaine, poppers, crack, or ecstasy.

${ }^{c}$ 4-hydroxybutanoic acid.

${ }^{\mathrm{d}}$ Solvents, lysergic acid diethylamide, ketamine.

${ }^{\mathrm{e}}$ The HIV Incidence Risk for MSM Scale was calculated based on sexual behavior in the previous 6 months (number of partners, condomless receptive anal intercourse, sex with HIV-positive partner, and use of stimulants; if $>10$ points, PrEP is recommended).

f“Unknown” answers scored 0 points on The HIV Incidence Risk for MSM Scale.

${ }^{\mathrm{g}}$ In the next 12 months.

${ }^{\mathrm{h}}$ Syphilis, gonorrhea, or rectal chlamydia. 
Table 3. Previous HIV testing and preferences ( $\mathrm{N}=5065)$. HIVST: human immunodeficiency virus self-testing; SUS: Brazilian public health system.

\begin{tabular}{|c|c|}
\hline Parameter & Total, n (\%) \\
\hline \multicolumn{2}{|l|}{ HIV testing } \\
\hline Never & $738(14.57)$ \\
\hline Once (lifetime) & $762(15.04)$ \\
\hline Once a year & $1073(21.18)$ \\
\hline More than once a year & $1171(23.12)$ \\
\hline Every time I am exposed & $311(6.14)$ \\
\hline Sporadically & $1010(19.94)$ \\
\hline \multicolumn{2}{|l|}{ Reasons for never testing $(n=738)$} \\
\hline No risk of be infected & $100(13.55)$ \\
\hline Not easy to reach health care provider & $50(6.78)$ \\
\hline Shame & $128(17.34)$ \\
\hline Afraid of being positive & $263(35.64)$ \\
\hline Lazy & $74(10.03)$ \\
\hline Other & $123(16.66)$ \\
\hline \multicolumn{2}{|l|}{ Best place for testing } \\
\hline At home & $2400(47.38)$ \\
\hline Health care provider & $1987(39.23)$ \\
\hline Pharmacy & $468(9.24)$ \\
\hline Community center & $61(1.20)$ \\
\hline Other & $149(2.94)$ \\
\hline \multicolumn{2}{|l|}{ Best way to obtain HIVST (if available at SUS) } \\
\hline Internet (home delivery) & $2094(41.34)$ \\
\hline Internet (pick somewhere) & $578(11.41)$ \\
\hline Pick up at a pharmacy & $1059(20.91)$ \\
\hline Pick up at a health care provider & $1126(22.23)$ \\
\hline Pick up at a nongovernmental organization & $104(2.05)$ \\
\hline Other & $104(2.05)$ \\
\hline
\end{tabular}

Figure 2. Willingness to use HIV prevention methods ( $\mathrm{n}=5065$ ). PrEP: preexposure prophylaxis; nPEP: nonoccupational postexposure prophylaxis.

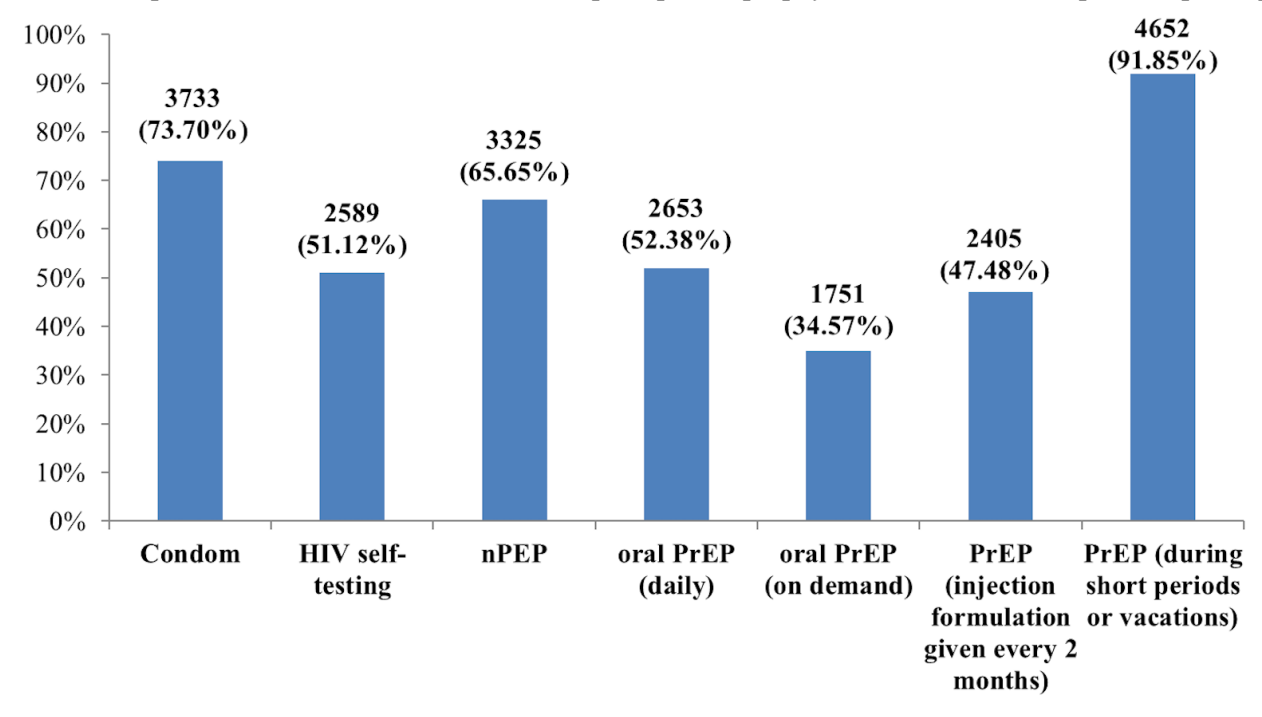




\section{Discussion}

Our findings provide important insights about the characteristics of Brazilian MSM based on two popular GSN apps for sexual encounters, and their preferences amidst the HIV prevention strategies. This information can potentially guide and support national prevention programs. Over half of the respondents would be willing to use daily oral PrEP if available through SUS, which is lower than previously reported in Brazil [21]. This finding is probably related to the fact that the previous studies also included individuals who were actively seeking PrEP, and thus possibly overestimated PrEP willingness. Nevertheless, our finding is consistent with reports from other settings [14,20-28,34] and represents a reassuring result, given that daily PrEP will soon be provided by SUS at no cost for MSM at higher risk of contracting HIV [48].

Our study showed that, in addition to daily oral PrEP, a high proportion of respondents were also interested in other PrEP formulations, such as injectable PrEP (2408/5065, 47.48\%). Long-acting injectable PrEP can be very beneficial among individuals for whom adherence to a daily oral regimen is challenging $[22,49,50]$. Cabotegravir, an integrase inhibitor that can be administered through intramuscular injection, is one of the products currently under clinical development for PrEP formulation [51]. Individuals' personal preferences and priorities may have a significant impact on acceptability, uptake, and retention of different PrEP modalities and the ability to choose among multiple contraceptive methods, which was shown to be associated with increased population coverage [52].

Although nPEP has been available at no cost through SUS since 2009, awareness, willingness, and use were lower than expected. This problem is highly concerning given that almost half of our sample reported unprotected anal sex. Similar results have been described from other settings with MSM-concentrated epidemics $[53,54]$.

Few of the respondents had heard about HIVST; however, half of them would be willing to use it and this strategy, which could increase serostatus awareness and facilitate integration into HIV care [55]. The acceptability of HIVST ranged from 21-98\% in studies among MSM [56], including a pilot study using blood-based HIVST in Brazil and Peru [57], and an Internet-based feasibility study using oral fluid, which was conducted in Brazil [58]. As social networking advertisements on HIVST were shown to be effective at increasing HIVST awareness and uptake [59,60], feasibility of HIVST distribution through apps for sexual encounters should also be further evaluated.

Although smartphones became the main devices used for Internet access, especially in lower income families [61], it is hard to estimate the proportion and possible selection bias of online studies. Most of the MSM included in this study were white and aged 25-36 years, and reported middle to higher income with more schooling years, which may not reflect the Brazilian MSM population. Some of these characteristics are in accordance with a systematic review, which showed that those using apps were younger, presented higher educational levels, reported higher incomes, had higher proportions of risky sexual behaviors, and were more likely to have tested for HIV in their lifetime compared to nonapp-using MSM [62]. In addition, our sample was similar to the one recruited on Grindr for a study in Los Angeles [63] and another from a social networking site for MSM in Latin America, Spain, and Portugal [38]. Indeed, studies have shown that online samples tend to be biased toward a lower median age, as younger MSM are over-represented on GSN apps [64]. Conversely, younger MSM aged 24 years or less was not the majority of this sample, perhaps because the content of the survey or the advertisement strategy was not attractive to this population.

Considering The HIV Incidence Risk for MSM Scale, most of the sample should be further evaluated for PrEP use, but perceived likelihood of getting HIV in next year was low. Moreover, rates of unprotected anal intercourse reported by study participants was high, which has also been found to be high among MSM who use Grindr in studies conducted in the United States [35,65] and among MSM from a website for sexual encounters in Latin America [38]. The CDC recommends that sexually active MSM should be tested annually, and clinicians should consider the potential benefits of more frequent HIV screening (eg, every three or six months) for some asymptomatic sexually active MSM, based on their individual risk factors, local HIV epidemiology, and local policies [66,67]. Almost $15 \%$ of the sample (738/5065) had never performed an HIV test and $15 \%(762 / 5065)$ were only tested once in their lifetime, which is almost two-fold higher than that observed in a US study using a GSN app [68], but much lower than that found in other Brazilian studies [2,69]. Knowledge of HIV status enables individuals to make decisions about behavioral strategies to reduce HIV transmission risks, such as serosorting [70-72], using condoms with partners who do not share the same HIV status, or restricting behaviors to partners who are HIV-positive and have undetectable viral loads (UVLs) or HIV-negative partners that take PrEP [73]. Disclosure of PrEP use and UVL is not uncommon among MSM using apps in the United States, and the majority of the respondents have engaged in condomless sex at least once based on this status [73]. This behavior is unknown in Brazil, as PrEP is still not available and information and knowledge about the relationship of UVL and HIV transmission is not widely spread. Hopefully this reality will change in the foreseeable future, and studies to evaluate this behavior shift are needed.

Binge drinking and tobacco and substance use were high in the study population, compared with the general population [74], which is consistent with previous reports [75,76]. In an online survey among MSM through Facebook in seven countries, including Brazil, it was observed that social networks and minority stressors can have significant effects on drug use and sex while drunk or high [77]. Binge drinking and drug use (eg, marijuana, amphetamines, poppers) in general have been associated with condomless intercourse [78-80]. A recent study in young lesbian, gay, and bisexual individuals showed that the use of marijuana is associated with sex with multiple partners [81]. Conversely, a lower prevalence of binge drinking and substance use was observed during the PrEP Brasil Study [10]. Nevertheless, public policies on HIV prevention still need to 
acknowledge and address the relationship between substance use and risk behaviors.

Moreover, our results provide evidence that MSM reporting higher risk behaviors were more willing to use daily PrEP, as observed in other studies [21,82-87]. Accordingly, our results show that those reporting higher or unknown perceived HIV risk and STI diagnoses in the last six months were also more willing to use daily PrEP. This is an important finding since PrEP is recommended to high-risk MSM. In addition, those not willing to use condoms were more willing to use PrEP. In a study comparing preferences for PrEP, condoms, and both PrEP and condoms, MSM reporting recent risk behaviors were more likely to prefer PrEP compared with condoms only, and less likely to prefer both methods compared with condoms only [88].

Unequivocally, this study has limitations. First, online studies are not probabilistic sampling strategies, thus precluding the generalizability of the findings. Given the cross-sectional nature of the data, causality and the direction of association may not be inferred. All collected data were self-reported by participants and may be subjected to bias, including social desirability bias. Our data were also subjected to recall bias due to 6-month or 12-month recall periods. There is also a concern about participants taking the survey multiple times. To avoid this issue, the first question of the survey was, "Are you answering this survey for the first time?" (4\% of participants answered "no" and were excluded from the study). Finally, we have measured intention to use PrEP, nPEP, condoms, and HIVST as a proxy of willingness. There are different methods for accessing PrEP willingness, as reviewed by Young and McDaid [89], and as such our results should be interpreted with care.

In summary, our observed high HIV risk scores suggest that most MSM would be eligible for PrEP, and that those who present risky sexual behaviors were more willing to use it. Notwithstanding, only 58\% (2932/5065) of individuals were aware of this prevention strategy. Additionally, awareness, willingness, and use of nPEP — which has been available in Brazil since 2009-were low. Efforts to increase awareness of new prevention strategies are urgently needed to create demand among those at the highest risk for HIV infection. Mobile health tools are a promising strategy to reach high risk MSM in Brazil.

\section{Conflicts of Interest}

Gilead Sciences covered the costs related to advertisement of the survey on Grindr and Hornet, but had no role in the study design, collection, analysis, or interpretation of data, the writing of the manuscript, or the decision to submit this manuscript for publication.

\section{Multimedia Appendix 1}

Factors associated with daily PrEP willingness.

[PDF File (Adobe PDF File), 35KB-Multimedia Appendix 1]

\section{References}

1. De Boni R, Veloso VG, Grinsztejn B. Epidemiology of HIV in Latin America and the Caribbean. Curr Opin HIV AIDS 2014 Mar;9(2):192-198. [doi: 10.1097/COH.0000000000000031] [Medline: 24356327]

2. Kerr LRFS, Mota RS, Kendall C, Pinho ADA, Mello MB, Guimarães MDC, HIVMSM Surveillance Group. HIV among MSM in a large middle-income country. AIDS 2013 Jan 28;27(3):427-435. [doi: 10.1097/QAD.0b013e32835ad504] [Medline: 23291540]

3. Ministério da Saúde do Brasil. Boletim Epidemiol\&oacute;gico de Aids 2016 URL: http://www.aids.gov.br/pt-br/pub/2016/ boletim-epidemiologico-de-aids-2016 [accessed 2017-09-24] [WebCite Cache ID 6thnB23ms]

4. Barbosa Júnior A, Szwarcwald CL, Pascom ARP, Souza Júnior PBD. [Trends in the AIDS epidemic in groups at highest risk in Brazil, 1980-2004]. Cad Saude Publica 2009 Apr;25(4):727-737 [FREE Full text] [Medline: 19347198]

5. Grant RM, Anderson PL, McMahan V, Liu A, Amico KR, Mehrotra M, iPrEx Study Team. Uptake of pre-exposure prophylaxis, sexual practices, and HIV incidence in men and transgender women who have sex with men: a cohort study. Lancet Infect Dis 2014 Sep;14(9):820-829. [doi: 10.1016/S1473-3099(14)70847-3] [Medline: 25065857]

6. Grant RM, Lama JR, Anderson PL, McMahan V, Liu AY, Vargas L, iPrEx Study Team. Preexposure chemoprophylaxis for HIV prevention in men who have sex with men. N Engl J Med 2010 Dec 30;363(27):2587-2599 [FREE Full text] [doi: 10.1056/NEJMoa1011205] [Medline: 21091279]

7. McCormack S, Dunn DT, Desai M, Dolling DI, Gafos M, Gilson R, et al. Pre-exposure prophylaxis to prevent the acquisition of HIV-1 infection (PROUD): effectiveness results from the pilot phase of a pragmatic open-label randomised trial. Lancet 2016 Jan 2;387(10013):53-60 [FREE Full text] [doi: 10.1016/S0140-6736(15)00056-2] [Medline: 26364263]

8. Molina J, Capitant C, Spire B, Pialoux G, Cotte L, Charreau I, et al. On-demand preexposure prophylaxis in men at high risk for HIV-1 infection. N Engl J Med 2015 Dec 3;373(23):2237-2246. [doi: 10.1056/NEJMoa1506273] [Medline: 26624850]

9. Molina J, Charreau I, Spire B, Cotte L, Chas J, Capitant C, ANRS IPERGAY Study Group. Efficacy, safety, and effect on sexual behaviour of on-demand pre-exposure prophylaxis for HIV in men who have sex with men: an observational cohort study. Lancet HIV 2017 Sep;4(9):e402-e410. [doi: 10.1016/S2352-3018(17)30089-9] [Medline: 28747274]

10. Hoagland B, Moreira RI, De Boni RB, Kallas EG, Madruga JV, Vasconcelos R, PrEP Brasil Study Team Clinical Trial Number 01989611. High pre-exposure prophylaxis uptake and early adherence among men who have sex with men and 
transgender women at risk for HIV Infection: the PrEP Brasil demonstration project. J Int AIDS Soc 2017 Apr 06;20(1):1-14 [FREE Full text] [doi: 10.7448/IAS.20.1.21472] [Medline: 28418232]

11. Lal L, Audsley J, Murphy DA, Fairley CK, Stoove M, Roth N, VicPrEP Study Team. Medication adherence, condom use and sexually transmitted infections in Australian preexposure prophylaxis users. AIDS 2017 Jul 31;31(12):1709-1714. [doi: 10.1097/QAD.0000000000001519] [Medline: 28700394]

12. Gandhi M, Murnane PM, Bacchetti P, Elion R, Kolber MA, Cohen SE, et al. Hair levels of PrEP drugs measure adherence and are associated with renal decline among men/transwomen in an open label PrEP study. AIDS 2017 Aug 21. [doi: 10.1097/QAD.0000000000001615] [Medline: 28832411]

13. De Baetselier I, Reyniers T, Nöstlinger C, Wouters K, Fransen K, Crucitti T, Be-PrEP-Ared Study Group. Pre-exposure prophylaxis (PrEP) as an additional tool for HIV prevention among men who have sex with men in Belgium: the Be-PrEP-ared study protocol. JMIR Res Protoc 2017 Jan 30;6(1):e11 [FREE Full text] [doi: 10.2196/resprot.6767] [Medline: 28135199]

14. Mimiaga MJ, Case P, Johnson CV, Safren SA, Mayer KH. Preexposure antiretroviral prophylaxis attitudes in high-risk Boston area men who report having sex with men: limited knowledge and experience but potential for increased utilization after education. J Acquir Immune Defic Syndr 2009 Jan 1;50(1):77-83 [FREE Full text] [doi: 10.1097/QAI.0b013e31818d5a27] [Medline: 19295337]

15. Biello KB, Colby D, Closson E, Mimiaga MJ. The syndemic condition of psychosocial problems and HIV risk among male sex workers in Ho Chi Minh City, Vietnam. AIDS Behav 2014 Jul;18(7):1264-1271 [FREE Full text] [doi: 10.1007/s10461-013-0632-8] [Medline: 24081899]

16. Barash EA, Golden M. Awareness and use of HIV pre-exposure prophylaxis among attendees of a seattle gay pride event and sexually transmitted disease clinic. AIDS Patient Care STDS 2010 Nov;24(11):689-691. [doi: 10.1089/apc.2010.0173] [Medline: 20863247]

17. Eisingerich AB, Wheelock A, Gomez GB, Garnett GP, Dybul MR, Piot PK. Attitudes and acceptance of oral and parenteral HIV preexposure prophylaxis among potential user groups: a multinational study. PLoS One 2012;7(1):e28238 [FREE Full text] [doi: 10.1371/journal.pone.0028238] [Medline: 22247757]

18. Wheelock A, Eisingerich AB, Ananworanich J, Gomez GB, Hallett TB, Dybul MR, et al. Are Thai MSM willing to take PrEP for HIV prevention? An analysis of attitudes, preferences and acceptance. PLoS One 2013;8(1):e54288 [FREE Full text] [doi: 10.1371/journal.pone.0054288] [Medline: 23342121]

19. Bil JP, Davidovich U, van der Veldt WM, Prins M, de Vrie HJC, Sonder GJB, et al. What do Dutch MSM think of preexposure prophylaxis to prevent HIV-infection? A cross-sectional study. AIDS 2015 May 15;29(8):955-964. [doi: 10.1097/QAD.0000000000000639] [Medline: 25915169]

20. Yi S, Tuot S, Mwai GW, Ngin C, Chhim K, Pal K, et al. Awareness and willingness to use HIV pre-exposure prophylaxis among men who have sex with men in low- and middle-income countries: a systematic review and meta-analysis. J Int AIDS Soc 2017 Jun 26;20(1):1-27 [FREE Full text] [doi: 10.7448/IAS.20.1.21580] [Medline: 28691439]

21. Hoagland B, De Boni RB, Moreira RI, Madruga JV, Kallas EG, Goulart SP, PrEP Brasil Study Team. Awareness and willingness to use pre-exposure prophylaxis (PrEP) among men who have sex with men and transgender women in Brazil. AIDS Behav 2017 May;21(5):1278-1287. [doi: 10.1007/s10461-016-1516-5] [Medline: 27531461]

22. Hall EW, Heneine W, Sanchez T, Sineath RC, Sullivan P. Preexposure prophylaxis modality preferences among men who have sex with men and use social media in the United States. J Med Internet Res 2016 May 19;18(5):e111 [FREE Full text] [doi: 10.2196/jmir.5713] [Medline: 27199100]

23. Karuga RN, Njenga SN, Mulwa R, Kilonzo N, Bahati P, O'reilley K, et al. "How I wish this thing was initiated 100 years ago! Willingness to take daily oral pre-exposure prophylaxis among men who have sex with men in Kenya. PLoS One 2016;11(4):e0151716 [FREE Full text] [doi: 10.1371/journal.pone.0151716] [Medline: 27073896]

24. Ferrer L, Folch C, Fernandez-Davila P, Garcia A, Morales A, Belda J, Ad hoc study group for PrEP acceptability. Awareness of pre-exposure prophylaxis for HIV, willingness to use it and potential barriers or facilitators to uptake among men who have sex with men in Spain. AIDS Behav 2016 Jul;20(7):1423-1433. [doi: 10.1007/s10461-016-1379-9] [Medline: 27022938]

25. Grov C, Whitfield THF, Rendina HJ, Ventuneac A, Parsons JT. Willingness to take PrEP and potential for risk compensation among highly sexually active gay and bisexual men. AIDS Behav 2015 Dec;19(12):2234-2244 [FREE Full text] [doi: 10.1007/s10461-015-1030-1] [Medline: 25735243]

26. Draper BL, Oo ZM, Thein ZW, Aung PP, Veronese V, Ryan C, et al. Willingness to use HIV pre-exposure prophylaxis among gay men, other men who have sex with men and transgender women in Myanmar. J Int AIDS Soc 2017 Jul 26;20(1):1-10 [FREE Full text] [doi: 10.7448/IAS.20.1.21885] [Medline: 28741332]

27. Patrick R, Forrest D, Cardenas G, Opoku J, Magnus M, Phillips G, et al. Awareness, willingness, and use of pre-exposure prophylaxis among men who have sex with men in Washington, DC and Miami-Dade County, FL: national HIV behavioral surveillance, 2011 and 2014. J Acquir Immune Defic Syndr 2017 Jul 01;75 Suppl 3:S375-S382. [doi: 10.1097/QAI.0000000000001414] [Medline: 28604442]

28. Holt M, Lea T, Schmidt H, Kolstee J, Ellard J, Murphy D, et al. Willingness to use and have sex with men taking HIV pre-exposure prophylaxis (PrEP): results of online surveys of Australian gay and bisexual men, 2011-2015. Sex Transm Infect 2017 Sep;93(6):438-444. [doi: 10.1136/sextrans-2016-052774] [Medline: 28108701] 
29. Grosskopf NA, LeVasseur MT, Glaser DB. Use of the Internet and mobile-based "apps" for sex-seeking among men who have sex with men in New York City. Am J Mens Health 2014 Nov;8(6):510-520. [doi: 10.1177/1557988314527311] [Medline: 24658284]

30. Holloway IW, Rice E, Gibbs J, Winetrobe H, Dunlap S, Rhoades H. Acceptability of smartphone application-based HIV prevention among young men who have sex with men. AIDS Behav 2014 Feb;18(2):285-296 [FREE Full text] [doi: 10.1007/s10461-013-0671-1] [Medline: 24292281]

31. Winetrobe H, Rice E, Bauermeister J, Petering R, Holloway IW. Associations of unprotected anal intercourse with Grindr-met partners among Grindr-using young men who have sex with men in Los Angeles. AIDS Care 2014;26(10):1303-1308. [doi: 10.1080/09540121.2014.911811] [Medline: 24754563]

32. Goedel WC, Duncan DT. Geosocial-networking app usage patterns of gay, bisexual, and other men who have sex with men: survey among users of Grindr, a mobile dating app. JMIR Public Health Surveill 2015;1(1):e4 [FREE Full text] [doi: 10.2196/publichealth.4353] [Medline: 27227127]

33. Phillips G, Magnus M, Kuo I, Rawls A, Peterson J, Jia Y, et al. Use of geosocial networking (GSN) mobile phone applications to find men for sex by men who have sex with men (MSM) in Washington, DC. AIDS Behav 2014 Sep;18(9):1630-1637. [doi: 10.1007/s10461-014-0760-9] [Medline: 24682866]

34. Young SD, Szekeres G, Coates T. The relationship between online social networking and sexual risk behaviors among men who have sex with men (MSM). PLoS One 2013;8(5):e62271 [FREE Full text] [doi: 10.1371/journal.pone.0062271] [Medline: 23658716]

35. Landovitz RJ, Tseng C, Weissman M, Haymer M, Mendenhall B, Rogers K, et al. Epidemiology, sexual risk behavior, and HIV prevention practices of men who have sex with men using GRINDR in Los Angeles, California. J Urban Health 2013 Aug;90(4):729-739 [FREE Full text] [doi: 10.1007/s11524-012-9766-7] [Medline: 22983721]

36. Holloway IW, Pulsipher CA, Gibbs J, Barman-Adhikari A, Rice E. Network influences on the sexual risk behaviors of gay, bisexual and other men who have sex with men using geosocial networking applications. AIDS Behav 2015 Jun;19 Suppl 2:112-122 [FREE Full text] [doi: 10.1007/s10461-014-0989-3] [Medline: 25572832]

37. McFarlane M, Bull SS, Rietmeijer CA. The Internet as a newly emerging risk environment for sexually transmitted diseases. JAMA 2000 Jul 26;284(4):443-446. [Medline: 10904506]

38. Biello KB, Rosenberger JG, Novak DS, Robertson AM, Mayer KH, Mimiaga MJ. Epidemiology of sexual health in the virtual environment: a multinational online survey of Spanish- and Portuguese-speaking men who use an internet sexual networking site. AIDS Behav 2014 Sep;18(9):1675-1685. [doi: 10.1007/s10461-014-0844-6] [Medline: 24980249]

39. Instituto Brasileiro de Geografia e Estatística (IBGE). Censo Brasileiro 2010 URL: https://censo2010.ibge.gov.br/painel/ [accessed 2017-09-24] [WebCite Cache ID 6thnaqdwp]

40. SurveyGizmo. 2017. URL: https://www.surveygizmo.com/ [accessed 2018-01-16] [WebCite Cache ID 6wWkJGmgs]

41. Hornet. 2018. URL: https://hornetapp.com/login [accessed 2018-01-16] [WebCite Cache ID 6wWkjVCoq]

42. Grindr. 2018. URL: https://www.grindr.com/ [accessed 2018-01-16] [WebCite Cache ID 6wWkTRTz7]

43. NIAAA Newsletter. 2004. NIAAA council approves definition of binge drinking URL: $\underline{\text { https://pubs.niaaa.nih.gov/publications/ }}$ Newsletter/winter2004/Newsletter Number3.pdf [accessed 2017-09-23] [WebCite Cache ID 6thnuzirQ]

44. Smith DK, Pals SL, Herbst JH, Shinde S, Carey JW. Development of a clinical screening index predictive of incident HIV infection among men who have sex with men in the United States. J Acquir Immune Defic Syndr 2012 Aug 01;60(4):421-427. [doi: 10.1097/QAI.0b013e318256b2f6] [Medline: 22487585]

45. Centers for Disease Control and Prevention. 2014. Preexposure prophylaxis for the prevention of HIV infection in the United States - 2014 a clinical practice guideline URL: https://www.cdc.gov/hiv/pdf/prepguidelines2014.pdf [accessed 2017-09-23] [WebCite Cache ID 6thoHaxKr]

46. Hosmer W, Stanley L. Applied Logistic Regression, 2nd edition. New York: John Wiley \& Sons, Inc; 2000.

47. Allison PD. Logistic regression using the SAS system: theory and application. 2nd edition. North Carolina: SAS Institute; 2012.

48. Ministério da Saúde do Brasil. 2017. Protocolo Clínico e Diretrizes Terapêuticas para Profilaxia Pré-Exposição (PrEP) de Risco à Infecção pelo HIV URL: http://www.aids.gov.br/pt-br/pub/2017/ protocolo-clinico-e-diretrizes-terapeuticas-para-profilaxia-pre-exposicao-prep-de-risco [accessed 2017-09-24] [WebCite Cache ID 6thoc5pjp]

49. Meyers K, Rodriguez K, Moeller RW, Gratch I, Markowitz M, Halkitis PN. High interest in a long-acting injectable formulation of pre-exposure prophylaxis for HIV in young men who have sex with men in NYC: a P18 cohort substudy. PLoS One 2014;9(12):e114700 [FREE Full text] [doi: 10.1371/journal.pone.0114700] [Medline: 25502768]

50. Greene GJ, Swann G, Fought AJ, Carballo-Diéguez A, Hope TJ, Kiser PF, et al. Preferences for long-acting pre-exposure prophylaxis (PrEP), daily oral PrEP, or condoms for HIV prevention among U.S. men who have sex with men. AIDS Behav 2017 May;21(5):1336-1349. [doi: 10.1007/s10461-016-1565-9] [Medline: 27770215]

51. Markowitz M, Frank I, Grant RM, Mayer KH, Elion R, Goldstein D, et al. Safety and tolerability of long-acting cabotegravir injections in HIV-uninfected men (ECLAIR): a multicentre, double-blind, randomised, placebo-controlled, phase $2 \mathrm{a}$ trial. Lancet HIV 2017 Aug;4(8):e331-e340. [doi: 10.1016/S2352-3018(17)30068-1] [Medline: 28546090] 
52. Ross J, Stover J. Use of modern contraception increases when more methods become available: analysis of evidence from 1982-2009. Glob Health Sci Pract 2013 Aug;1(2):203-212 [FREE Full text] [doi: 10.9745/GHSP-D-13-00010] [Medline: 25276533]

53. McDougal SJ, Alexander J, Dhanireddy S, Harrington RD, Stekler JD. Non-occupational post-exposure prophylaxis for HIV: 10-year retrospective analysis in Seattle, Washington. PLoS One 2014;9(8):e105030 [FREE Full text] [doi:

10.1371/journal.pone.0105030] [Medline: 25140868]

54. Chomchey N, Woratanarat T, Hiransuthikul N, Lertmaharit S, Lohsoonthorn V, Teeratakulpisarn N, et al. Factors associated with intention to take non-occupational HIV post-exposure prophylaxis among Thai men who have sex with men. J Virus Erad 2017 Jul 01;3(3):128-139 [FREE Full text] [Medline: 28758020]

55. Rendina HJ, Jimenez RH, Grov C, Ventuneac A, Parsons JT. Patterns of lifetime and recent HIV testing among men who have sex with men in New York City who use Grindr. AIDS Behav 2014 Jan;18(1):41-49 [FREE Full text] [doi: 10.1007/s10461-013-0573-2] [Medline: 23925515]

56. Figueroa C, Johnson C, Verster A, Baggaley R. Attitudes and acceptability on HIV self-testing among key populations: a literature review. AIDS Behav 2015 Nov;19(11):1949-1965 [FREE Full text] [doi: 10.1007/s10461-015-1097-8] [Medline: $\underline{26054390]}$

57. Volk JE, Lippman SA, Grinsztejn B, Lama JR, Fernandes NM, Gonzales P, et al. Acceptability and feasibility of HIV self-testing among men who have sex with men in Peru and Brazil. Int J STD AIDS 2016 Jun;27(7):531-536 [FREE Full text] [doi: 10.1177/0956462415586676] [Medline: 25971262]

58. De Boni RB. A Hora é Agora (The time is now): Comprehensive Approach to HIV Testing and Linkage to Care for Men Who Have Sex with Men in Curitiba, Brazil. 2017 Jul 23 Presented at: International AIDS Society (IAS) Conference; 2017; Paris, France URL: http://programme.ias2017.org/Programme/Session/168

59. Huang E, Marlin RW, Young SD, Medline A, Klausner JD. Using Grindr, a smartphone social-networking application, to increase HIV self-testing among Black and Latino men who have sex with men in Los Angeles, 2014. AIDS Educ Prev 2016 Aug;28(4):341-350 [FREE Full text] [doi: 10.1521/aeap.2016.28.4.341] [Medline: 27427928]

60. Rosengren AL, Huang E, Daniels J, Young SD, Marlin RW, Klausner JD. Feasibility of using Grindr(TM) to distribute HIV self-test kits to men who have sex with men in Los Angeles, California. Sex Health 2016 May 23. [doi: 10.1071/SH15236] [Medline: 27209076]

61. Brazilian Internet Steering Committee. ICT households 2015 survey on the use of information and communication technologies in Brazilian households. 2015. URL: https://www.cgi.br/media/docs/publicacoes [accessed 2017-09-23] [WebCite Cache ID 6thpG6AsM]

62. Zou H, Fan S. Characteristics of men who have sex with men who use smartphone geosocial networking applications and implications for HIV interventions: a systematic review and meta-analysis. Arch Sex Behav 2017 May;46(4):885-894. [doi: 10.1007/s10508-016-0709-3] [Medline: 27043837]

63. Burrell ER, Pines HA, Robbie E, Coleman L, Murphy RD, Hess KL, et al. Use of the location-based social networking application GRINDR as a recruitment tool in rectal microbicide development research. AIDS Behav 2012 Oct;16(7):1816-1820 [FREE Full text] [doi: 10.1007/s10461-012-0277-z] [Medline: 22851153]

64. Marcus U, Hickson F, Weatherburn P, Schmidt AJ, EMIS Network. Age biases in a large HIV and sexual behaviour-related internet survey among MSM. BMC Public Health 2013 Sep 10;13:826 [FREE Full text] [doi: 10.1186/1471-2458-13-826] [Medline: 24020518]

65. Flores SA, Bakeman R, Millett GA, Peterson JL. HIV risk among bisexually and homosexually active racially diverse young men. Sex Transm Dis 2009 May;36(5):325-329. [doi: 10.1097/OLQ.0b013e3181924201] [Medline: 19295470]

66. Centers for Disease Control and Prevention. Prevalence and awareness of HIV infection among men who have sex with men --- 21 cities, United States, 2008. MMWR Morb Mortal Wkly Rep 2010 Sep 24;59(37):1201-1207 [FREE Full text] [Medline: 20864920]

67. DiNenno EA, Prejean J, Irwin K, Delaney KP, Bowles K, Martin T, et al. Recommendations for HIV screening of gay, bisexual, and other men who have sex with men - United States, 2017. MMWR Morb Mortal Wkly Rep 2017 Aug 11;66(31):830-832 [FREE Full text] [doi: 10.15585/mmwr.mm6631a3] [Medline: 28796758]

68. Grov C, Rendina HJ, Parsons JT. How different are men who do not know their HIV status from those who do? Results from an U.S. online study of gay and bisexual men. AIDS Behav 2016 Sep;20(9):1989-1999 [FREE Full text] [doi: 10.1007/s10461-015-1284-7] [Medline: 26767536]

69. Brito AM, Kendall C, Kerr L, Mota RM, Guimarães MD, Dourado I, et al. Factors associated with low levels of HIV testing among men who have sex with men (MSM) in Brazil. PLoS One 2015;10(6):e0130445 [FREE Full text] [doi: 10.1371/journal.pone.0130445] [Medline: 26098559]

70. Steward WT, Remien RH, Higgins JA, Dubrow R, Pinkerton SD, Sikkema KJ, et al. Behavior change following diagnosis with acute/early HIV infection-a move to serosorting with other HIV-infected individuals. The NIMH Multisite Acute HIV Infection Study: III. AIDS Behav 2009 Dec;13(6):1054-1060 [FREE Full text] [doi: 10.1007/s10461-009-9582-6] [Medline: $\underline{19504178]}$ 
71. Marks G, Millett GA, Bingham T, Lauby J, Murrill CS, Stueve A. Prevalence and protective value of serosorting and strategic positioning among Black and Latino men who have sex with men. Sex Transm Dis 2010 May;37(5):325-327. [doi: 10.1097/OLQ.0b013e3181c95dac] [Medline: 20081556]

72. Tieu H, Li X, Donnell D, Vittinghoff E, Buchbinder S, Parente ZG, et al. Anal sex role segregation and versatility among men who have sex with men: EXPLORE Study. J Acquir Immune Defic Syndr 2013 Sep 01;64(1):121-125 [FREE Full text] [doi: 10.1097/QAI.0b013e318299cede] [Medline: 23945255]

73. Newcomb ME, Mongrella MC, Weis B, McMillen SJ, Mustanski B. Partner disclosure of PrEP use and undetectable viral load on geosocial networking apps: frequency of disclosure and decisions about condomless sex. J Acquir Immune Defic Syndr 2016 Feb 01;71(2):200-206 [FREE Full text] [doi: 10.1097/QAI.0000000000000819] [Medline: 26761520]

74. Fonseca AM, Galduróz JCF, Noto AR, Carlini ELDA. Comparison between two household surveys on psychotropic drug use in Brazil: 2001 and 2004. Cien Saude Colet 2010 May;15(3):663-670 [FREE Full text] [Medline: 20464178]

75. Fallin A, Goodin A, Lee YO, Bennett K. Smoking characteristics among lesbian, gay, and bisexual adults. Prev Med 2015 May;74:123-130 [FREE Full text] [doi: 10.1016/j.ypmed.2014.11.026] [Medline: 25485860]

76. Tomkins A, Ahmad S, Cannon L, Higgins SP, Kliner M, Kolyva A, et al. Prevalence of recreational drug use reported by men who have sex with men attending sexual health clinics in Manchester, UK. Int J STD AIDS 2017 Jan 01:956462417725638. [doi: 10.1177/0956462417725638] [Medline: 28835196]

77. Chard AN, Metheny NS, Sullivan PS, Stephenson R. Social stressors and intoxicated sex among an online sample of men who have sex with men (MSM) drawn from seven countries. Subst Use Misuse 2017 Aug 09:1-9. [doi: 10.1080/10826084.2017.1322985] [Medline: 28792280]

78. Celentano DD, Valleroy LA, Sifakis F, MacKellar DA, Hylton J, Thiede H, Young Men's Survey Study Group. Associations between substance use and sexual risk among very young men who have sex with men. Sex Transm Dis 2006 Apr;33(4):265-271. [doi: 10.1097/01.olq.0000187207.10992.4e] [Medline: 16434886]

79. Stueve A, O'Donnell L, Duran R, San DA, Geier J, Community Intervention Trial for Youth Study Team. Being high and taking sexual risks: findings from a multisite survey of urban young men who have sex with men. AIDS Educ Prev 2002 Dec;14(6):482-495. [Medline: 12512849]

80. Ludford KT, Vagenas P, Lama JR, Peinado J, Gonzales P, Leiva R, Peruvian HIV Sentinel Surveillance Working Group. Screening for drug and alcohol use disorders and their association with HIV-related sexual risk behaviors among men who have sex with men in Peru. PLoS One 2013;8(8):e69966 [FREE Full text] [doi: 10.1371/journal.pone.0069966] [Medline: 23936364]

81. Zhang X, Wu L. Marijuana use and sex with multiple partners among lesbian, gay and bisexual youth: results from a national sample. BMC Public Health 2017 Jan 05;17(1):19 [FREE Full text] [doi: 10.1186/s12889-016-3905-0] [Medline: 28056883]

82. Krakower DS, Mimiaga MJ, Rosenberger JG, Novak DS, Mitty JA, White JM, et al. Limited awareness and low immediate uptake of pre-exposure prophylaxis among men who have sex with men using an Internet social networking site. PLoS One 2012;7(3):e33119 [FREE Full text] [doi: 10.1371/journal.pone.0033119] [Medline: 22470438]

83. Sineath RC, Finneran C, Sullivan P, Sanchez T, Smith DK, Griensven FV, et al. Knowledge of and interest in using preexposure prophylaxis for HIV prevention among men who have sex with men in Thailand. J Int Assoc Provid AIDS Care 2013;12(4):227-231. [doi: 10.1177/2325957413488184] [Medline: 23708677]

84. Holt M, Murphy DA, Callander D, Ellard J, Rosengarten M, Kippax SC, et al. Willingness to use HIV pre-exposure prophylaxis and the likelihood of decreased condom use are both associated with unprotected anal intercourse and the perceived likelihood of becoming HIV positive among Australian gay and bisexual men. Sex Transm Infect 2012 Jun;88(4):258-263. [doi: 10.1136/sextrans-2011-050312] [Medline: 22290327]

85. Aghaizu A, Mercey D, Copas A, Johnson AM, Hart G, Nardone A. Who would use PrEP? Factors associated with intention to use among MSM in London: a community survey. Sex Transm Infect 2013 May;89(3):207-211. [doi: 10.1136/sextrans-2012-050648] [Medline: 23015689]

86. Lebouché B, Engler K, Machouf N, Lessard D, Thomas R. Predictors of interest in taking pre-exposure prophylaxis among men who have sex with men who used a rapid HIV-testing site in Montreal (Actuel sur Rue). HIV Med 2016 Feb;17(2):152-158. [doi: 10.1111/hiv.12286] [Medline: 26177691]

87. Hoots BE, Finlayson T, Nerlander L, Paz-Bailey G, National HIV Behavioral Surveillance Study Group. Willingness to take, use of, and indications for pre-exposure prophylaxis among men who have sex with men-20 US Cities, 2014. Clin Infect Dis 2016 Sep 01;63(5):672-677 [FREE Full text] [doi: 10.1093/cid/ciw367] [Medline: 27282710]

88. Mansergh G, Herbst JH, Mimiaga MJ, Holman J. Preference for condoms, antiretroviral preexposure prophylaxis, or both methods to reduce risk for HIV acquisition among uninfected US Black and Latino MSM. J Acquir Immune Defic Syndr 2015 Dec 01;70(4):e153-e155. [doi: 10.1097/QAI.0000000000000810] [Medline: 26302430]

89. Young I, McDaid L. How acceptable are antiretrovirals for the prevention of sexually transmitted HIV?: a review of research on the acceptability of oral pre-exposure prophylaxis and treatment as prevention. AIDS Behav 2014 Feb;18(2):195-216 [FREE Full text] [doi: 10.1007/s10461-013-0560-7] [Medline: 23897125] 


\author{
Abbreviations \\ AIDS: acquired immune deficiency syndrome \\ AOR: adjusted odds ratio \\ CDC: Centers for Disease Control and Prevention \\ GHB: 4-hydroxybutanoic acid \\ GSN: geosocial networking \\ HIVST: human immunodeficiency virus self-testing \\ MSM: men who have sex with men \\ nPEP: nonoccupational postexposure prophylaxis \\ OR: odds ratio \\ PEP: postexposure prophylaxis \\ PrEP: preexposure prophylaxis \\ STI: sexually transmitted infection \\ SUS: Brazilian public health system \\ UVL: undetectable viral loads
}

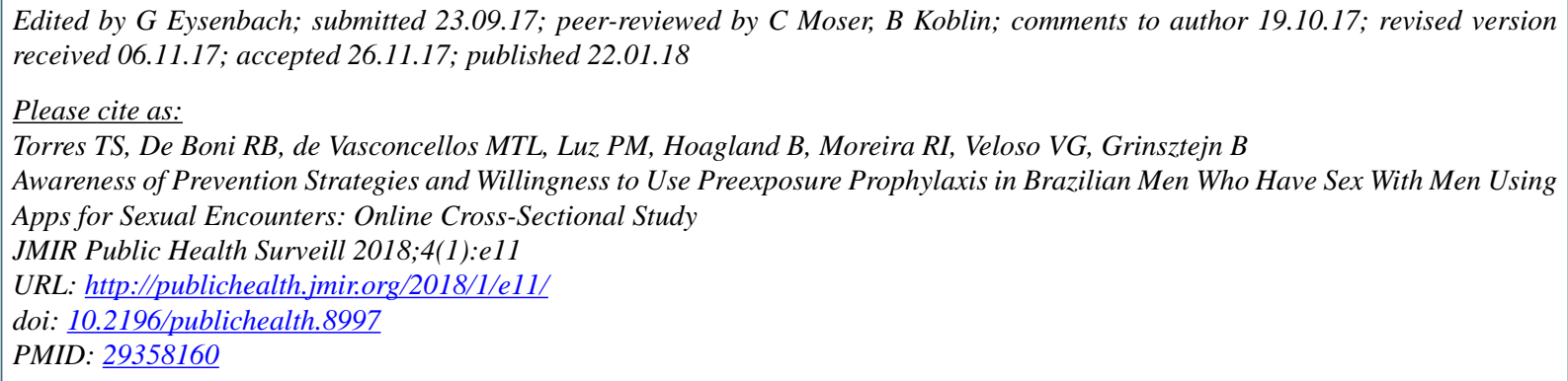

(C)Thiago Silva Torres, Raquel Brandini De Boni, Mauricio T L de Vasconcellos, Paula Mendes Luz, Brenda Hoagland, Ronaldo Ismerio Moreira, Valdilea Gonçalves Veloso, Beatriz Grinsztejn. Originally published in JMIR Public Health and Surveillance (http://publichealth.jmir.org), 22.01.2018. This is an open-access article distributed under the terms of the Creative Commons Attribution License (https://creativecommons.org/licenses/by/4.0/), which permits unrestricted use, distribution, and reproduction in any medium, provided the original work, first published in JMIR Public Health and Surveillance, is properly cited. The complete bibliographic information, a link to the original publication on http://publichealth.jmir.org, as well as this copyright and license information must be included. 